\title{
On analysing space from a strategic-relational institutionalist perspective: the Cultural Park for Children in Cairo
}

\author{
PIETER VAN DEN BROECK *, MONA ABDELWAHAB **, KONRAD \\ MICIUKIEWICZ †, JEAN HILLIER ‡
}

\footnotetext{
* Department of Architecture, urbanism and planning, University of Leuven, Leuven, Belgium, ** Department of Spatial Planning, University of Groningen, Groningen, Netherlands † School of Architecture, Planning and Landscape, Newcastle University, UK, ‡ RMIT University, Melbourne, Australia
}

\begin{abstract}
Recent contributions to strategic spatial planning theory claim to develop a relational perspective to planning and space. In this paper we explore this perspective further. We review the relational approach of planning and its origins, against Fordist 'territory-based' systems, and then explore how the relational approach conceptualises aspects of space, including scale, position, regionalisation, materiality and identity, development, representation. We focus on strategic-relational institutionalist theory. The Cultural Park for Children in Cairo, is introduced as a case to question the relational perception of space, the conceptions of space and spatial strategies of different actants, spatial representations and frames. We conclude by indicating how a strategic-relational institutionalist approach may contribute to a greater understanding of the spatial dynamics of actants and their institutional frames and argue for the inclusion of different conceptions of space in planning processes and inclusionary co-emergence of physical and social planning.
\end{abstract}

keywords: relational space, strategic spatial planning, strategic-relational approach, institutionalist planning, Cultural Park for Children, Caïro

\section{Introduction}

Strategic spatial planning:

'is about dreaming alternative futures about place qualities, their potentials and possibilities. It is also about actively shaping futures and the practices, now and in the future, which might bring more desirable futures into being' (Healey, 2010: 37).

'refers to self-conscious collective efforts to re-imagine a city, urban region or wider territory, and to translate the result into priorities for area investment, conservation measures, strategic infrastructure investments and principles of land use regulation' (Healey, 2004:46).

Over the last decade, strategic spatial planning theory and practice have reacted to the rationalist boundaries of the management science models of strategic planning by engaging with particular features of 'uncertainty' in planning arenas, and by introducing an approach to governance and decision-making based on a variety of (often institutionally-based) planning theories and practices. (Albrechts 2001; Albrechts, Healey and Kunzmann, 2003; Healey, 2007; Moulaert and Mehmood, 2009). As such, 'planning moves away from the idea of government as the mobiliser of the public sector, providing solutions to problems, towards an idea of governance as the capacity to substantiate the search for creative and territorially differentiated solutions to problems/challenges' (Albrechts, 2003: 918). Strategic spatial planning, has become much more a mode of integrating complex agendas - through spatial strategy making, including democratic consultation - rather than a structure for matching functional boxes with spatial availabilities (Healey 1999). In this perspective, 
space and spatial quality are produced as a result of collective place-shaping efforts (Healey, 2008:3) that involve various human and non-human actants in different relations of power through subjectivation, organisation, and practices of signification (Hillier, 2011) performing complex interrelations and multiple space-time relational dynamics (Healey, 2006).

Post-rationalist strategic spatial planning theory thus claims to develop a relational perspective to planning and space. In this paper we explore this perspective further. We briefly review the relational perception of planning in planning theory, referring to influences from the social sciences, against the 'territory-based' systems of the Fordist era. We then explore how the relational approach conceptualises various aspects of space: scale, position, regionalisation, materiality and identity, development, representation, (after Healey, 2004). Drawing on Van den Broeck's (2010, 2011) strategic-relational institutionalist planning theory we elaborate a strategic-relational perspective on planning and space. The Cultural Park for Children in Cairo is introduced as a case study to further explore the planning and consideration of space, questioning, in particular, the relational perception of space, the role of the planner/designer, power strategies and representation. Whilst not exemplifying strategic spatial planning practice across a large metropolitan area, the case illustrates well the complex search for creative solutions, dreaming alternative futures through collective place-shaping efforts as Albrechts and Healey suggested above. We conclude by indicating how a strategic-relational institutionalist approach might contribute to a greater understanding of the spatial dynamics of actants and their institutional frames and argue for the inclusion of different conceptions of space in planning processes and the inclusionary co-emergence of physical and social planning.

\section{Relational perspectives on strategic spatial planning}

Following societal changes from the end of the 1960s, planning theory and practice underwent considerable change in many Western countries. The transition towards a post-Fordist system of economic production and consumption brought about new understandings of space, spatiality and spatial planning. The complex, amorphous, unstable and contingent socio-spatial configurations that emerged as a result of the dismantling of hierarchical redistributive structures of the welfare state and retrenched social policy under the new political-economic-spatial orders (Sassen, 1991; Fainstein, 2001; Harvey, 2005), have put in question modernist conception of planning as rational-comprehensive social intervention (Sandercock, 1998) and questioned the privileged status of professional planning knowledges and instruments (Alden et al, 2001).

With the decline of the welfare state in the Western world, strategic planning not only lost a clear defined project and resources to implement it, but also - in the face of growing diversity and social fragmentation the notion of the 'public' whose 'interest' it was called to defend has become problematic (Versteeg and Hajer, 2010). From a 'scientific' 'technique' for professional experts to 'administer' physical space in 'balanced' development, planning became a sphere of communicative action (influenced by Habermas, 1984, 1987) where planners as 'critical friends' (Forester, 1989) negotiated between business coalitions, corporate interests, local communities and civil society organisations. As Vigar, Graham and Healey (2005: 1408) suggest, 'there is an important link here between releasing the capacity to imagine the city in multiple ways in urban policy and planning, and the search for more collaborative ways of expressing concepts of cityness in spatial strategies, through the exploration of local contingencies, their meanings and consequences'. This means departing from an uncontested use of technical knowledge and linear concept of time and space (Balducci, 2010: 55) and a move towards examination of new potentialities arising from inclusive negotiation, social differences and conflicts (Albrechts, 2003) in the spirit of more inclusionary ethical practice (Howe, 1994; Hendler, 1995; Campbell, 2006) as well as seeking to conciliate bottom-up institutional dynamics with the (transformed) enabling institutions required to implement planning agendas (Moulaert and Mehmood, 2009).

The vision of a plan or strategy as an end-product was gradually being abandoned in favour of - inter alia - a focus on collaborative strategy-making which recognises 'that the future is changing along the path from present to future, which means that it cannot be known in advance' (Concilio, 2010: 282). In line with that consideration, Friedmann (2004) has proposed turning from long-range statutory plans to more flexible planning strategies, Innes and Booher (1999) write of bricolaging knowledge/practice resources and Hillier (2007, 2011) and Lehtovuori (2010) suggest speculative yet structured experimentation in the spatial as a way forward. There is increasing acceptance of a need to reinscribe conceptualisations of a world of space 'out-there' to be discovered with those of space as performative process ('spacing'); prescriptive/normative utopian goal-driven master plans with innovative, flexible, trajectories of agonistic learning (Hillier, 2003; 
Pløger, 2004); entities that 'are' with entities that transform, emerge or become (adapted from Amin and Thrift, 2005: 237). This means accepting a 'world of continuous variation, becoming and change, rather than one of constancy, being and predictability' (Doel, 1996, cited in Dewsbury, 2000: 488) as practices of spatial planning and governance have tended to do, while Grosz (2001: 149) suggests that practitioners 'abandon the fantasy of controlling the future while not abdicating the responsibility of preparing for a better future than the present'.

\section{Relational conceptions of space}

Within the field of spatial planning praxis, the shift within spatial planning from a rational-comprehensive to a strategic approach resembles how the traditional 'essentialist', 'Euclidean' way of seeing space has been contested by a relational view which stresses connections/relations between diverse meanings, identities, actions, places, and so on (Healey, 2004).

Such an approach implies a departure from the traditional conceptualisation of space as territorial entity a container which is given different functions (social, cultural, economic, administrative) - towards an understanding of space as a social, cultural, economic, political and ecological construction. In this approach the local and global are inherently interconnected. Hierarchies are seen as less important than the spatial reach of networks and meshworks. Poststructuralist thinkers may describe this as a rhizome which develops multiple connections in any direction, in any order, of any size, as compared with a hierarchically-branched tree (see Deleuze and Guattari, 1987).

Rather than structured through a hierarchy of scales - from global, through geo-regional, national, regional, urban, to very local scales of neighbourhoods and housing units - spaces play different roles as nodes in various networks (Healey, 2006). Healey $(2004,2006)$ and Amin (2004) point to a critical distinction between hierarchical and network or relational geographies. Whilst in hierarchical geography, scales were understood in terms of their 'reach' of a relationship in space and time, relational geography looks at scales as 'multilayered' (Massey, 2005) sites of interaction between local and global processes. This, however, does not always entail supplanting the local by the global or the primacy of horizontal networks over hierarchical structures and the coming of a flat ontology of space (DeLanda, 2004). Albrechts and Mandelbaum (2005) remind us that networks are additions to rather than replacements for hierarchies and bureaucracies. The new relational approaches, which problematize anti-territorial conceptions, consider space 'folded' rather than 'flat', construed by mutually interrelated hierarchical and network topologies and inter-scalar processes that cut across territorial dependencies, projects and aspirations (Jones, 2009; MacCann and Ward 2010).

The more dynamic in their spatial constitution that actant networks become, the more difficult it is to delimit or narrow the range of local issues and interests to be discussed at particular scales. Amin (2004) suggests that both politics of place and conceptualisations of cities and regions should be revisited so as to capture 'their plural connections [....], multiple geographies of affiliation, linkage and flow [...] and spatial formations of continuously changing composition, character, and reach' (Amin, 2004: 34-40). This requires rethinking not only scalar and territorial conceptions of space but also 'unitary forms of territorial citizenship' (Healey, 2006: 538). New post-national forms of citizenship (urban, regional or European) unravel the subjects of politics of place who have multiple and multi-scalar affinities, different views on what citizenship is, and stakes in distant territories of which they are not citizens (Amin, 2012). The point is that the 'geography will not be simply territorial.' (Massey, 2005: 184). This dispersion and multiplicity of post-territorial everyday life and citizenships constructs spaces as sites of fragmentation and uncertainty, but also opens up new political and cultural possibilities (Appadurai, 1990). Physical fabrics, social relations, actants, humans and non-humans are all involved in complex and contingent processes of folding together or apart. The rising cultural diversity and socio-spatial unevenness of post-Fordist spaces bring about a need for embedding articulations of difference, conflict and power-plays in the practice of planning, as authors such as Forester (1989), Flyvbjerg (1998), Hillier (2002) and Pløger (2004) demonstrate.

Physical spaces are considered as socially constructed and entangled - socially perceived, experienced, and shaped - and thus always classed, gendered, racialised. Spatial identities - which are regarded here as sites of negotiation - are historically changing and continually emerging (Healey, 2004) as a result of the social practices and interactions, individual emotions, and mental constructs which bring them into being. Relational planning practices turn towards the assessment of both physical and social qualities of spaces, which is based not upon values intrinsic to objects (and ideal templates for these objects), but upon experiential value of these objects which are identified by perceiving, thinking, feeling subjects whose socio- 
subjective perceptions are relational: dependent on the nature of the experienced objects, cultural, class, racial and gendered identities and spatial competences of experiencing subjects, as well as subjective elements. Rather than build or reconstruct essentialised spatial identities, strategic planning in this setting should use available knowledge and imaginative resources to mediate conflictive interests and challenge hegemonic claims and identities.

\section{A strategic-relational institutionalist perspective on planning and space}

Within the myriad of new conceptions of strategic planning and its relational epistemologies of space and place, this paper mobilises an institutionalist - and more specifically a strategic-relational - perspective on planning and space. Institutionalist analyses in planning are part of a broad stream of 'critical institutionalism' inspired by Bourdieu's (1984 [1979 Fr]) structuralist constructivism and Giddens' (1984) structuration theory, which investigate dynamics and interplays between structure and agency. Institutions in such analyses do not necessarily equate to organisations. They are understood as settings of norms and rules - both formal (legal regulations and procedures) and informal (habits, routines and constraints of daily life) which structure social interaction (Giddens, 1984; Gualini, 2001; Healey, 1999 and 2005). Institutionalisation involves the 'fixing' (albeit temporarily) of certain ways of thinking and doing as accepted practices.

Planning in institutionalist analyses is understood as a social process, rather than as a technical exercise, which seeks to interrelate the active work of individuals within social processes (the level of agency) with the power of system forces, such as economic organisation, political organisation, social dynamics and natural forces (the level of structure of social relations) (Healey, 2007: 198). The state in these analyses is not conceptualised as a homogeneous force but as a networked ensemble, or assemblage, which is open to changes in interactions with the micro-practices of everyday life and collective action which carries innovative governance capacity.

An institutionalist theory or analysis of spatial planning, then examines the norms of discourse and practice, and implications of these norms for structuring how the planners see their worlds and how they consequently seek to conciliate bottom-up institutional dynamics with institutional settings and planning agendas (Healey, 2005; Moulaert and Mehmood, 2009). Rather than focus on technologies of communicative practice, institutionalist planning practice looks at how collective action can innovate and transform (or not) wider planning cultures and institutionalised systems of action, and as such moves parallel to and beyond the communicative paradigm (Healey, 2005).

One major strand of institutionalist planning theory - sometimes coined as institutional evolution focuses on the ways planning instruments are shaped by the societal contexts from which they emerge and in which they operate. Another strand focuses on methods of institutional design bringing about change in society, building institutional capacity capable of changing social relations, decision making mechanisms and discourses. In order to further operationalise institutionalist planning theory and connect both strands, Van den Broeck (2010, 2011, with Servillo 2012) - follows Jessop's (2001, with Brenner and Jones, 2008) strategic-relational approach and regards planning as embedded in an 'institutional field'. Rather than focusing on institutions in planning, this means seeing planning as an institutionalized practice, as 'a set of practices itself subject to processes of institutionalization' (Gualini 2001:51), guided not only by a technical rationality but by a multiplicity of social rationalities. An institutional field consists of both actants and their practices, and of institutions expressed and examined in terms of each other: institutions in terms of action and action in terms of institutions.

A strategic-relational institutionalist (SRI) perspective thus involves examining how - at any given time particular institutions may privilege (but not determine) some actants, some actions, some strategies etc. over others in 'structurally inscribed strategic selectivities', and the ways - if any - in which actants take account of this differential privileging when choosing a course of action, 'structurally oriented strategic calculation' (Jessop 2001). Van den Broeck $(2010,2011)$ elaborates the institutional field in which planning is embedded, as a number of socio-technical ensembles of individual and collective actants organised in relevant social groups on the one hand and technical (planning instruments and procedures), cognitive (knowledge systems), socio-economic (social relations and allocation of resources), socio-political (social relations and governance configurations) and discursive (production of meaning) institutions organised in institutional frames on the other.

From an SRI perspective, planning (practice and theory) is thus not a monolith operating within institutions, but both agency and institutions. As an institutionalised practice, planning theory and practice 
have different forms which are struggled over by many individual and collective actants, who, in the process, become organised in different relevant social groups, which in their turn are structured by the institutional frames these groups continuously (re)produce, maintain and, to a certain extent, transform. To avoid a onesided actant-oriented view, the practices of planning actants thus have to be seen as pre-structured by the very institutional frames they act strategically upon. Equally, to avoid a deterministic perspective, the institutional frames - strategically selective with respect to the practices of planning actants - have to be analysed as resulting from previous actions of planning actants and relevant social groups who embed their values and interests in the institutional frames. The interactions between actants and institutions over time can be referred to as reflexively-recursively dialectal, thereby (re)producing, maintaining, transforming, both planning actants, relevant social groups and their strategic calculations and also planning instruments, institutional frames and their strategic selectivities. Planning and transformation processes are to be analysed as institutional dynamics in which continuity and discontinuity, institutional stability and institutional transformation interact. Rather than follow a linear pattern, these processes exhibit routes of bifurcations, power struggles, missed opportunities, dead ends, choices with no return, and so on, path-dependent on previous institutionalization processes.

Finally, the SRI perspective focuses on the ways particular individual and collective actants succeed or fail to imbue their values and interests into institutional frames; how institutional frames embody compromises between different values and interests and concomitant power relations and who dominates these compromises; how these structurally inscribed values and interests and concomitant power structures in turn inform the behaviour of different planning actants and who benefits from this. Planning is thus deeply socio-political, not just because of actants' attempts to manipulate planning and the political struggle over the choice of planning instruments, but in its very (strategically selective and institutional) nature.

The SRI perspective clearly has spatial implications. Since institutions - and their strategic selectivities are fundamentally spatial and temporal (Jessop 2001), so is strategic-relational institutionalist planning theory. According to Jessop (2001), spatio-temporal characteristics fundamentally constitute institutions; specific institutions support specific 'spatialities' and 'temporalities'; and changes in strategies can change short term limitations in long term opportunities and vice versa. Thus, a strategic-relational institutional analysis should pay careful attention both to (a) the temporalities and spatialities inscribed in specific institutional forms and (b) the differential temporal and spatial horizons of various actants and their capacities to shift horizons, modify temporalities and spatialities, jump scales, and so forth (Jessop 2001). Spatial organisation and transformation are thus inherent to the socio-territorial organisation and transformation in a given area. In other words, processes of spatial transformation are connected in a nonlinear way to socio-economic and socio-political processes of social transformation. The latter include the spatially specific, spatially negotiated and spatially embedded transformation of spatial relations (Moulaert 2009). Spatial transformation thus expresses power relations and compromises embedded in actants' strategic calculations and institutions' strategic selectivities. Analysis of the socio-political characteristics of planning practices and theories should, therefore, include evaluation of their territorial (i.e. the localisation of economic, social and political practices) and spatial (the spatial organisation, design, spatial lay-out) dimensions.

Expanding planning-theoretical conceptions of space (reviewed above) with SRI's relational perspective of space, we can identify several dimensions for empirical analysis of spatial transformation.

- Institutionalised perceptions of space. In general the SRI perspective and its relational social constructivist position imply that different conceptions and productions of space and spatial quality are (and should be) present in planning processes. SRI questions planning practice and theory as for whom (power confirming?, power challenging?): whose space and whose spatial qualities are produced, designed, negotiated, represented (or not); whose spatialities (and temporalities) are expressed and embedded and in which spatialized conflicts and compromises; which institutional frames (in their different cognitive, social, political, cultural, discursive dimensions) are (or are not) expressed in/through actants' - human and non-human - spatialities (and temporalities).

Two major institutionalised frames are container space and relational space. A container space holds objects inside its boundaries, with the implication that it can continue to exist in the absence of matter, like monuments frozen in time and space. In contrast, 'spatiality' (of actants in relevant social groups, institutional frames, and their transformation) implies that space should not be understood as the neutral backdrop of social actions and relations, but rather as indelibly mixed in these relations, both produced by and defining them. 
- $\quad$ Power and ethics. Actants' differential capacities to produce and transform institutional frames (structurally oriented strategic calculation) and institutions' differential structuring of actants' spatial practices (structurally inscribed strategic selectivity) entail that specific interests, values, compromises, actants' power relations and institutionalised power structures are embedded in specific planning practices, their methods and theories and their spatial outcomes. The socio-political nature of planning practice and theory implies that each planning method, its theory and its spatial outcome embody an (implicit or explicit) ethical position. We argue for an analysis evaluating spatial selectivities (who benefits and who does not? who has the power to transform institutionalised spatial compromises and who does not?) and a planning praxis expresssing an ethical position in favour of the fulfilment of basic needs for all, including non-conventional and disadvantaged actants such as children, (see case study below).

- $\quad$ Scale. As opposed to container space, spatialities of both actants and their institutional frames - their meanings, purposes, acts - manifest themselves in/on different spaces, territories, scales. Empirical analysis should uncover these spaces, operational scales of actants and institutions through tracings, mappings, analyses of uses of space, discourse analysis and so on .

- $\quad$ Social space and materiality. SRI analysis shows how differing physical, human and non-human social dimensions are spatially expressed, organised, negotiated, perceived, conceptualised and represented. The relational perspective of SRI means that planning physical space, also implies a perspective on social transformation in its different dimensions (cognitive, organisational, sociopolitical, socio-economic, cultural, discursive). This happens implicitly or explicitly. The issue is which perspective of social space is embedded in planning physical space and whose needs are adressed (or not).

- (Post-)Representation. SRI analysis shows how actants with different ways of perceiving, conceptualising and representing space act in space and have access to planning processes. Different perceptions, conceptions and representations of space - to a certain extent expressing actants' different institutional frames - and different ways of perceiving, conceptualising and representing space are - or should be - embedded in spatial compromises that are conceived, proposed and designed. A relational perspective reconnects representation of space with actants' multiple experiences rather than the traditional two and three dimensional representations that tend to normalise both uses and physical forms. The term post-representation is used by some authors (e.g. Hillier, 2007) to describe this perspective where every act of speech, writing and imaging is representative.

- $\quad$ Spatial dynamics. Institutionalist analysis is fundamentally historical, showing how different actants and their institutional frames and the spatialities of both co-evolve in negotiated spatial transformation processes and in multiple development trajectories; how actants consciously or unconsciously (re)produce and transform institutional frames and their stabilities; how they are structured in doing so; and how actants shift spatial horizons, modify temporalities and spatialities, jump scales, and so forth, thus producing change and instabilities. In what follows we interweave consideration of spatial dynamics into our analysis of the Cultural Park for Children in Cairo.

\section{Planning and the consideration of space: Cairo Space and the Cultural Park for Children (1992-2009)}

'...the insertion of the park [was perceived to have] ... generated a renewed sense of community by extending its presence into the surrounding streets. The residents take pride in their neighbourhood as well as their park.' (Aga Khan Award for Architecture, 1992)

As explained above, SRI is a critical institutionalist theory rooted in 'old' institutionalist approaches of, for instance, the German historical school and US old institutionalism, which integrates issues of underdevelopment and research on the Global South, but also builds on a structure - agency approach, rendering it applicable to a wide range of cases and research topics internationally. Mobilising the dimensions explained above, we now review the development of the Cultural Park for Children in Cairo (see Abdelwahab, 2009, 2010). As a long spatial planning, design and transformation process, involving 
variegated agendas of multiple actants, mobilisation of imaginative resources, coordination of planning efforts, it was shaped by local governance cultures, imaginations, the continuous design of the social needs of local inhabitants and the relations between tradition and everyday practices. Firstly, however, we present a brief analytical context.
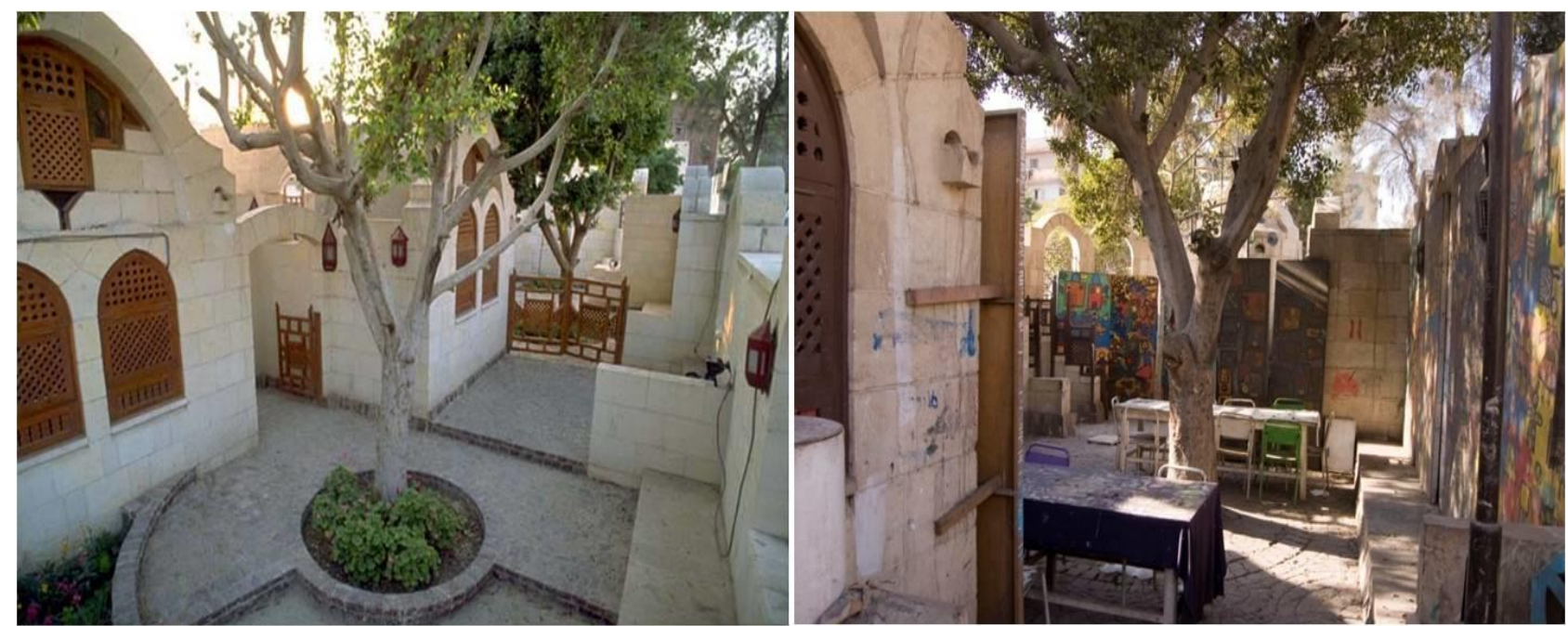

Figure 1. The Cultural Park for children before (1992 - left) and after (2009- right) transformation (source: left: AKTC: http://archnet.org/libraryfiles, right Abdelwahab 2010);

The Cultural Park for Children was built in 1992, in the old historic district of Al-Sayyida Zeinab near Ibn Tulun mosque in Cairo. The project involved a long design process (started in 1983) and development of an old degenerated park and its northern boundary. Significantly, the park won both a national award for the schematic design and an international award for the design process. This reflects a consensus between national and international perspectives of Cairo's space and her architectural image. Abdelwahab (2009) highlights the significant socio-spatial transformation of the park. She demonstrates that realities of the park's everyday life, some eighteen years after its development, showing indifference to the original design scheme (see Figure 1), creating conflicting community activity and isolating the park from its context, AlSayyida Zeinab.

Figure 2 presents a brief chronology of the Cultural Park's construction over the remnants of the old park of 'Al-Houd Al-Marsoud'; the design process that involved both designer and community; the building ceremony that preceded construction of the park; and finally the use and adaptation of the park.

We approach the case as a relational process between the designer, park manager, political and community actants based on open structured interviews with the manager; discourse analysis of the designer's published writings and interviews and the government's involvement through media declarations. Analysis also includes examination of archival photographs of the park in 1992 (http:archnet.org/libraryfiles) and its development until 2009, (see Abdelwahab, 2010, forthcoming). Further, the role and impact of the Aga Khan Trust for Culture (AKTC) as the awarding committee of a prestigious international prize, is included through an analysis of the Committee's technical reports.

\section{Institutionalised Perceptions of Space}

We can identify the spatialities of the various actants involved, the designer, park manager and community, AKTC, as well as the institutional frames these actants operate within, including those of cultural symbolism, community identity, children's practices and needs, heritage and religion. The park as a nonhuman actant is indirectly addressed in the analysis. Figure 3 below schematically expresses the actants involved and how they operate within different - overlapping, competing, conflicting etc. - institutionalised spatialities. 


\section{The Old Park}

Detiorated Al-Houd Al-Marsoud park built in the late $19^{\text {th }}$ century

Air-raid shelters (1967 war), administrative buildings were added

Many workshops occupied the place

1983 The Design Competition

Egyptian Ministry of Culture competition to design the park

Contract awarded to designer Dr A.I.Abdelhalim

[1978, PhD thesis, Building Ceremony, USA)

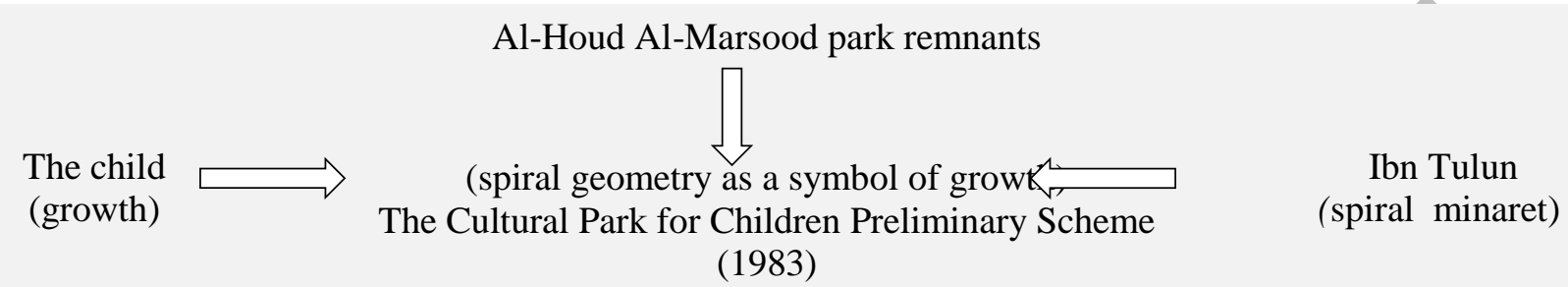

(1983)

1983-1985 The Design Process

Community Involvement in Design

resulted in program change:

Design proposal: a nursery to serve working mothers by

providing a care service for their children

Community response: a library to serve children find useful

activities on holidays, reading

1987 The Building Ceremony

- Spatial transformation of the original design in reflection to ceremony rituals

- The community involved through a full scale model rather than professional drawings

\section{7-1989 Park Construction}

An international organisation based in the USA

\section{The AKTC award 1992}

(a particular interest in the continuity of heritage of Islamic cities and identity)
Related to the founders of the Historic city of Cairo

\section{2-2009 The Use of the Park}

The manager claims the park design as unsuccessful and unsafe:

- The library is fitted in a small space with poor lighting

- The finishing material (sharp stones and wooden details) have to be removed

\section{Instead:}

- Children's activity is accommodated in the shaded areas of the park

- A multi-purpose unit is built which provided a larger activity area rather than the small, traditionallyinspired spaces provided by the designer, who refused to design the new unit

Figure 2. The chronology of Cultural Park for Children, Al-Sayyida Zeineb (source: authors).

Firstly, the designer claims professional authority over space, the power of an expert over both the political and community actants and the authority to impose his theoretical approach ('the opportunity to test out my theories' (Abdelhalim, 1988:140)). He refers to his doctoral thesis on 'the building ceremony', which he conducted in the USA in 1978 awarding him the symbolic power of high-level knowledge.

The designer's reading of the park revolved around two main lines of thought. The first expressed a nostalgia for the past and tradition - place as both decaying remnant of the glory of the past - and more importantly, in terms of the continuing tradition of the Al-Sayyida Zeinab festival, its ceremony and rituals. The second line of thought expressed the authoritative position of the architect through his professional knowledge; the role of the 'educated' architect in understanding and interpreting people and place in order to 'change the society' and 're-establish' new relations. The designer's reading thus reflects two images; the glory of the past through its physical monuments and the continuing festival of Al-Sayyida Zeinab, and the 
designer's modern western education, theories and practice. This double authority is spatially expressed in the institutional frames of 'the historic city' and the 'disciplining city' (Figure 3) and initiated a conflict between the designer, the park manager and the community, as we discuss below.

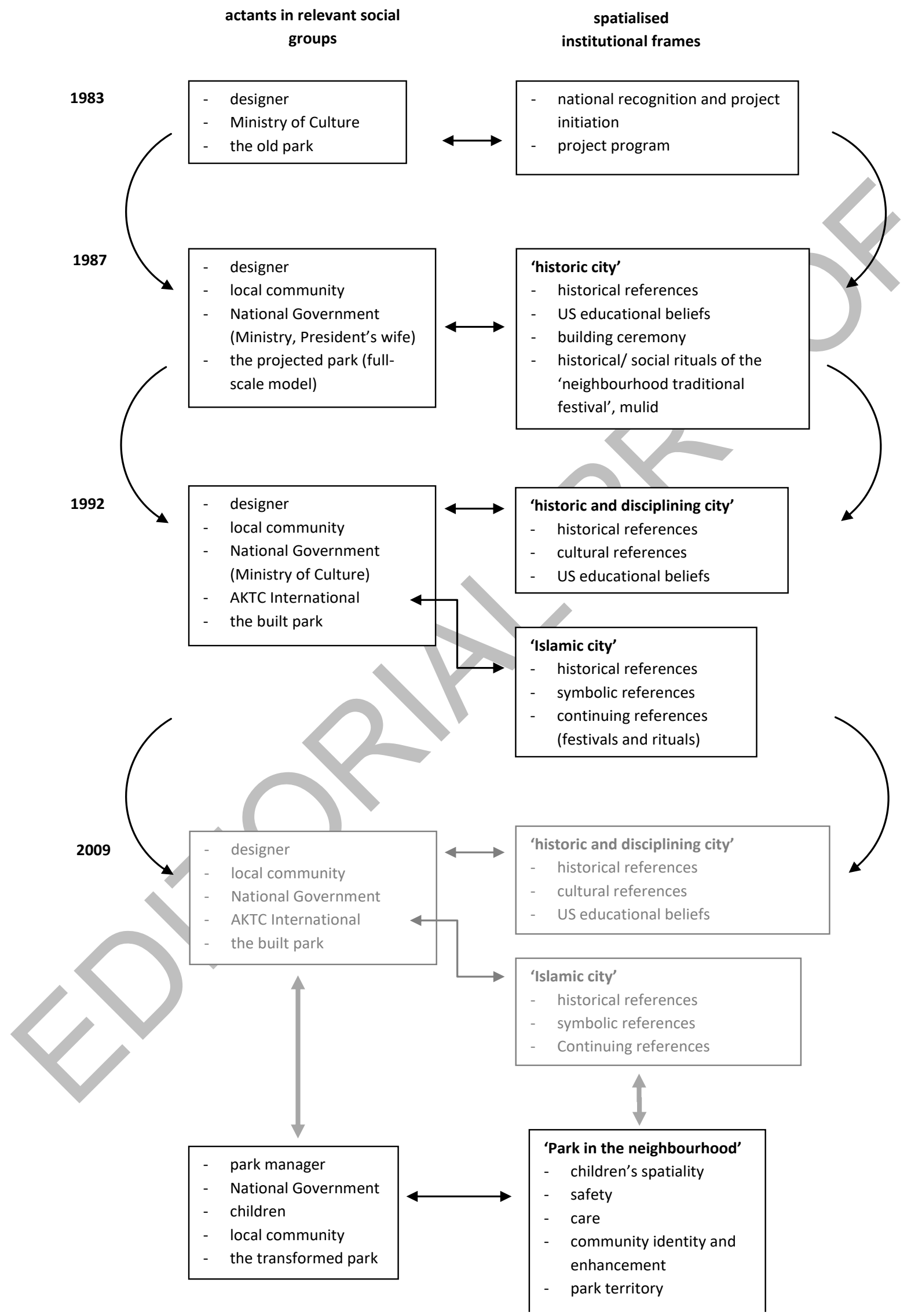

Figure 3. Dynamics of actants and their spatialised institutional frames (source: authors). 
In contrast, the manager claims the administrative authority as well as the 'ownership' of the park as a previous local resident member of the community. She embodies a nostalgic perspective of the space (frame 'Park in the neighbourhood' in Figure 3) as she struggles with the designer's institutional frame and its preinscribed selectivity and she succeeds in establishing a different course of action (see Figure 2).

Thirdly, the AKTC's agenda as a global organisation for Islamic culture has been woven into the planning process. The AKTC and its approach to Cairo as a whole are deeply embedded in an image of the old Islamic city founded by the Fatimids (institutional frame 'traditional Islamic city', Figure 3), their heritage. This is due to the AKTC's strong connection to the Aga Khan, the descendant of Fatima, the daughter of the Prophet, whose followers are the founders of Historic Cairo 969 AD, (Beeson, 1969).

In brief, the park space, and the various involved actors, are institutionalised between the heritage of the past - monuments, rituals and traditions - and the dilemmas of the present - everyday life and need to progress. The designer is thus acting between this space of heritage and his modern role to reform and reinstitutionalise the space. The manager however, is defending yet another perspective of this heritage against the modern interventions. Finally, the 'International' prize awarded by the AKTC is rooted in the heritage past.

\section{Container space versus relational space}

All the above actants perceived space as a container. This resulted in the separation of the physical from the social, and a reduction of the 'social' to the 'symbolical'.

As Abdelhalim, the designer, walks through the neighbourhood of Al-Sayyida Zeinab, he sees the minaret of Ibn Tulun mosque (879 AD) standing in the middle of the district of Al-Sayyida Zeinab, '...one of the oldest, most densely populated and poorly maintained quarters in Cairo' (Abdelhalim, 1988:140). He perceives space as a container which holds time: history, monuments, and traditions, and socio-cultural values inside this container.

The cultural park is built on the remnants of Al-Houd Al-Marsoud park. So the designer explores the rhythms, geometric patterns and their co-ordinates within the old neighbourhood, and identifies the objects within the place, as landmarks - the minaret Ibn Tulun, the domes of mausoleums, the land patterns, existing palm trees from the old Park and so on... 'The task of the designer is to disentangle these containers of order and discover their underlying geometry' (Abdelhalim, 1988:143). These objects within the container were analysed and synthesised to develop the theme and design of the park. For example, the spiral minaret of Ibn Tulun Mosque in the setting is used to develop spiral geometry in the park design, (see Figure 4). The designer conceived space as a spatial container of Islamic historic references that reads and interprets the spatial patterns within both the park setting and Al-Sayyida Zeinab district in which the park forms a new layer juxtaposed to the old one.

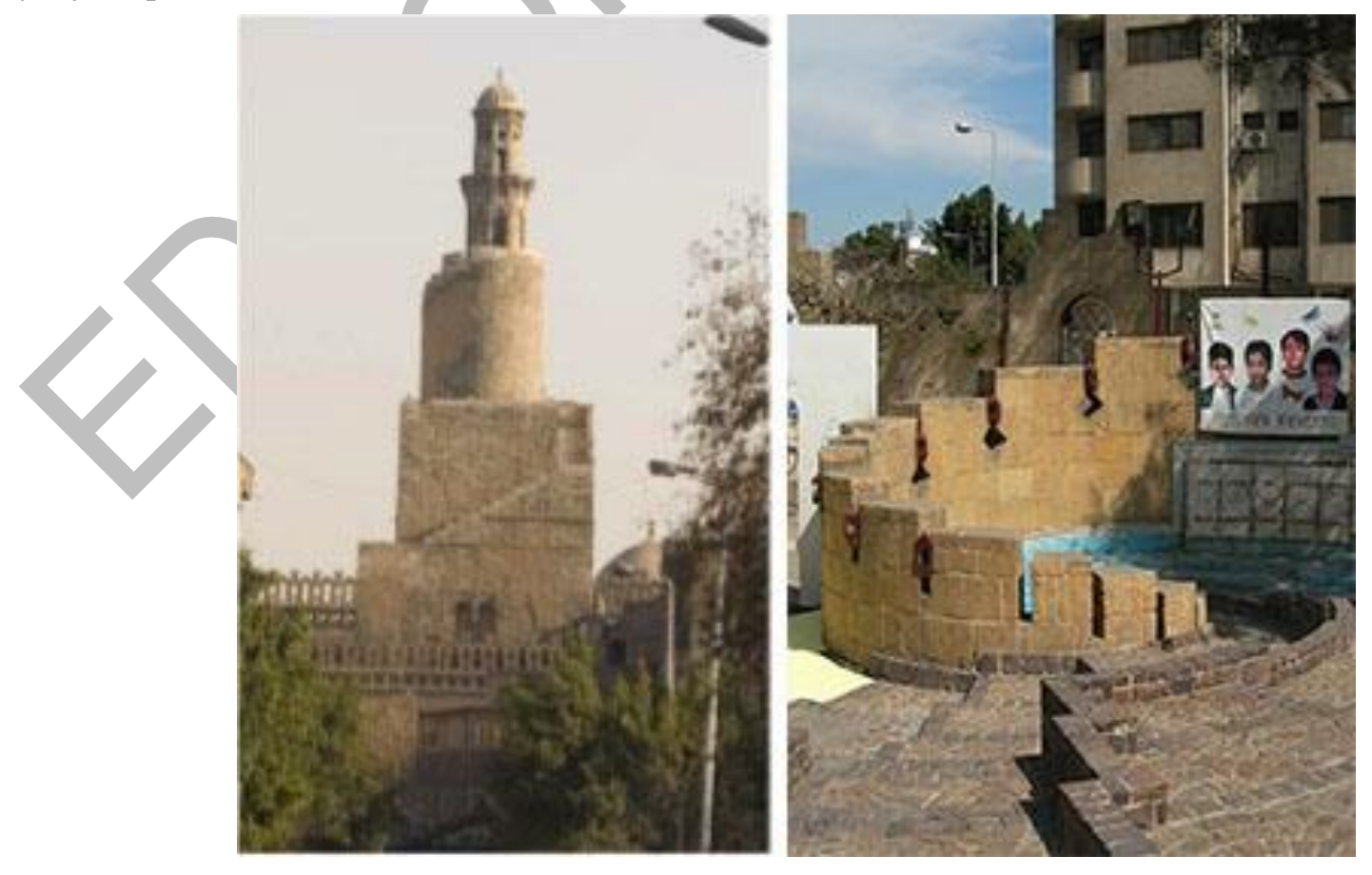

Figure 4. Historic references reflected in the park design (source: Abdelwahab 2010). 
However, the designer's approach to the park design also aimed to extend the park space outward, to interact with the neighbourhood community of which it is a part. Accordingly, he rejected the development of well defined boundaries to the park within the neighbourhood. The park edges are designed as permeable walls that allow access between park and surroundings. Abu Al-Dahab Street was designed to facilitate and encourage this movement. The designer's approach to the park thus holds two conceptions of space, a container space of the historic and spatial objects, and a relational space between the park and neighbourhood. However, he identifies this relational space through the physical boundaries, edges and walls of the park, itself a separate container space inside the neighbourhood.

\section{Power and Ethics}

We can identify a power struggle over the Cultural Park space between the designer (and part of the community) in an institutional frame of heritage, symbolism and Western education on the one hand, and the park manager, children and another part of the community in an institutional frame of community identity and children's practices on the other. The designer's initial approach to the park claims authority over both physical and social space, braced by his belief in the park as a tool for education for children and the local community about their 'heritage', and the ability to change this society through physical space (Abdelhalim,1996). He regarded his role as being to 'interpret and understand the culture' and re-establish the connections between this culture and the built environment (Abdelhalim, 1996). This role also involved attracting the adult community into actively participating in the design process (see Figure 2) rather than playing a more passive role responding to professional drawings. The dialogue with the community changed the proposed park program from incorporating a child care centre and nursery to a library.

This culturally institutionalised dialogue, however, excluded the children users of the park who were spoken for by adults (strategic selectivity). The children's lost ownership of the park was reclaimed by the manager in a perceptible conflict with the design strategy (Abdelwahab, 2009). Her interventions removed most of the wooden artefacts and other finishing materials which the designer stipulated and which the manager deemed inappropriate for the children's use and provided shaded areas for children's activities. These interventions brought about an intense struggle of strategic calculation between the designer and the manager about the spatial quality of the park (Hassan, 1996). "The Cultural Park was built for Children, but they were not allowed to use it. It is like an expensive toy parents buy for the child but then do not allow them to play with because it might break.... I think it is because we were trying to wrestle from the people their authentic culture and adapt it to the expectations of the educated. We wanted to intellectualize it to the expectations of the educated.' (Abdelhalim in Hassan, 1996: 13).

The park manager spoke as a community member, an ex-resident of Al-Houd Al-Marsoud neighbourhood, i.e. a user. Her former childhood home lies behind the park. Accordingly, a struggle, embedded in the event of empowering the user, developed between the designer claiming professional knowledge and attempting to 'educate' the child and change society through his park, his theory, and his practice and the manager, who claimed the power to approach the park holding professional (administrative) authority, and who attempted to imprint this authority on the park and, as a user, to emphasize the child and society relationship. The manager asserted firmly that the park design was inappropriate for child use. She criticised the designer for not including the child in his design approach: the programme did not provide outdoor shaded areas for child activity; the indoor spaces were too small to accommodate different activities; the stairs, fountains and other finishing materials were hard, with sharp edges and were unsuitable for children playing and running about (Figure 1). In other words, the park did not fulfil the basic needs of children despite purporting to be a Cultural Park for Children. The struggle cumulated in the manager's request for the designer to introduce a multi-purpose indoor space to accommodate various children's activities, especially on hot or rainy days, but which the designer refused. A multi-purpose building was designed and built using another designer in a spatial compromise.

\section{Scale}

We have noted the implications of the designer's claimed authoritative judgement of spatial quality. This authority also extends to the planning strategies with regard to scale. The designer mostly refers to the park as the 'community' park and recognizes the wider socio-cultural locational context. The manager, however, describes the park as the 'child's park', concerned with a child's activity and actions inside the park.

The AKTC, an international institute, holds a different and much more geographically extensive perspective of Al-Sayyida Zeinab, in relation to Cairo in general, than does the designer. AKTC considered 
the old city to be a rich place with considerable potential, reflecting several layers of history. The historic district within the old city is perceived as a place 'composed of different urban configurations and offers several layers of architectural expression, ... a rich variety of monuments ..., residential buildings from the ottoman and late Mamluk period ..., side by side with modern and more recent buildings' (Akbar, 1992).

\section{Social Space and Materiality}

The designer approached the materiality of the park through symbolic and metaphorical values and representations. The park design was drawn 'from the interpretation of the Ibn Tulun minaret'. 'The spiral of the minaret, clearly visible from the site symbolises the idea of growth, which was taken as the main theme for the Park, to give form to what was common between children and the Park..., life.'(Abdelhalim, 1986: 68). This was complemented by another layer of reading of the community rituals in the Sayyida Zeinab Festival. This reading was developed through a 'building ceremony', which in the designer's words 'suggests some kind of contradiction since building involves construction, finance, and law, while ceremony is associated with rituals, festivity, and regeneration' and in simple words is 'the integration between both culture and production' (Abdelhalim, 1988: 140). Accordingly, a full-scale model of the park design, fashioned from wooden poles and canvas, was introduced into the festival event, with platforms and terraces marked on the ground. Dancers, musicians and artists were invited to participate as well as the local community of Al-Houd Al-Marsoud. These social rituals thus added another layer to the original physical plan inspired by the minaret. The physical design scheme of the park was refined, reflecting the circular dance movements typical of the choreography during the ceremony. This supposedly helped the initiation of a connection between the Park and the community, which gradually involved the people in the community in the design process and programme; '...a link between the activities of building and the culture of the community...' (Abdelhalim, 1988: 148).

\section{(Post-)Representation}

The planning and representation of the park design reflect a conflict between traditional and non-traditional perspectives. As we highlighted above, the event of the festival involved the interaction between dancers and artists and the full-scale model of the park. Paradoxically, these dynamic social interactions helped the production of a traditional representation of the park, manifested in the physical plan (Figure 5).

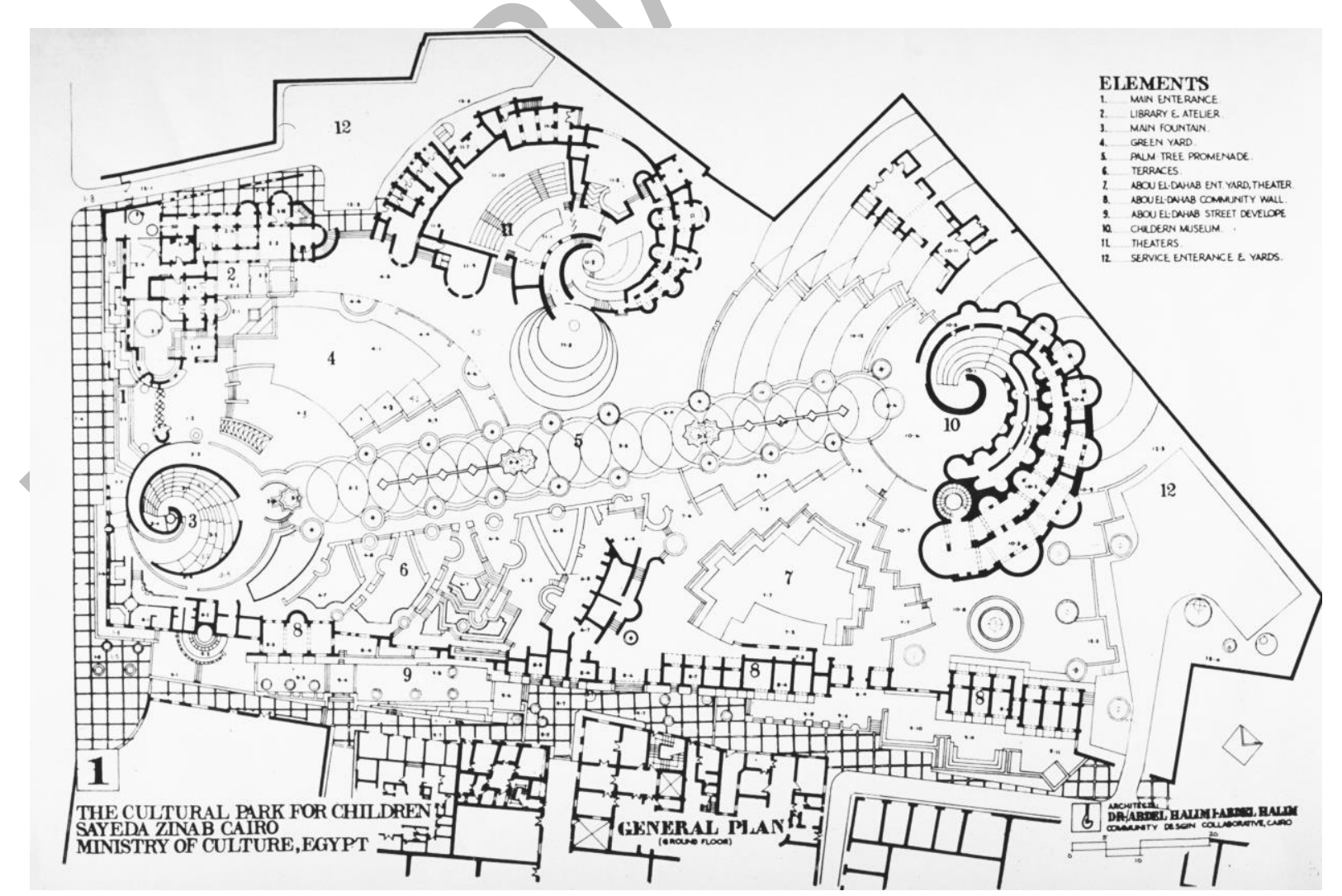

Figure 5. The designer's representation of the park (source: AKTC: http://archnet.org/libraryfiles). 
Moreover, the representation of the park's physical and social space is indifferent to temporality as it connects to historic monuments and traditional rituals in the container-space, but disconnects from the everyday life and wider socio-culture context of the local inhabitants. The designer regarded the community through a perspective of a modern (Western) 'individualistic' society, and accordingly, he proposed inclusion of a nursery and child care centre to help working mothers. However, the realities of the dynamics of this community did not require this nursery, as working mothers leave their babies with their neighbours while older children play in the streets, supervised by other community members who work in the cafés and shops, thus monitoring the neighbourhood from strangers.

\section{Conclusions}

We have briefly reviewed shifts in spatial planning theory from a Fordist rational comprehensive to a postFordist strategic and relational perspective on planning and space. We explained how a strategic-relational institutionalist (SRI) planning theory regards planning practices and theories (as praxis) as part of a dynamic institutional field of actants in institutional frames and especially how the SRI approach might contribute to a relational perspective of planning and space. This relational perspective on space analyses spatialities of actants and institutional frames, questions whose space and spatial qualities are being developed and structured by which spatialised institutional frames, and explores existing power relations and power structures. Expanding existing relational perspectives in planning theory with the SRI perspective, enabled us to identify several dimensions for empirical analysis of spatial transformation.

Our analysis of the Cultural Park for Children in Cairo showed how three predominant socio-spatial configurations of actants and their institutional frames interacted and conflicted, and how this interaction has produced the spatial transformation of the 'Cultural Park for Children' since 1992. Firstly, the designer of the park - operating within a frame dominated by his (Western) education - designed the park mainly for the educated, based on symbols of growth and referring to history and traditional culture, thus reducing the social space to an ideal-typical cultural-symbolic dimension. Secondly, the park manager - supported by most of the local community and representing the community's children - started from a nostalgic dream of her childhood in the neighbourhood, but responded to the present everyday activity and needs of the children and the social realities of the community, which induced a power struggle with the conception, representation and design of space expressed by the designer's institutional frame. Finally, the Aga Khan international award (AKTC) expressed an institutional frame (largely overlapping with the designer's frame), constituted by broad symbolic elements of history, heritage and religion and spatialised through references to the historic Islamic city of old Cairo.

The analysis shows how the conflict between the designer and the manager is embedded in a struggle over different definitions, conceptions, appropriations, scales etc. of space (intellectual versus noneducational, historical versus contemporary, static versus dynamic, historical-cultural versus historicalsociological, planned versus lived, abstract-religious versus concrete-religious, and so on), different mobilisations of different instruments and spatialised institutional frames and different interests of individual and collective actors embedded in different and dynamic coalitions.

The SRI perspective not only offers analytical meaning (uncovering the multiple spatialities, temporalities and their transformations active in concrete spatialised planning processes), but also has consequences for strategic spatial planning practice. An SRI perspective argues for inclusion of different expressions, perceptions, conceptions and representations of space (and of ways of doing this) in planning processes. SRI further defends an ethical position in favour of the fulfilment of basic needs for all, including nonconventional and disadvantaged actants such as children. Planning/design is regarded as a collective learning process in space, in which non-conventional and disadvantaged activities and actants can have an impact on the planning agenda and its spatial expressions. Furthermore, SRI urges planning theorists and practitioners to develop perspectives crosscutting different spaces, scales and so on of actants and institutions and to contribute to the elaboration of spatialised compromises by facilitating actans in shifting spatial horizons, modifying temporalities and spatialities, jumping scales. Finally, an SRI planning approach implies a coproduction of physical and social planning, in which perspectives on physical transformation are developed together with perspectives on social transformation in their different cognitive, organisational, sociopolitical, socio-economic, cultural and discursive dimensions. 


\section{Acknowledgements}

This paper is part of the SPINDUS research project funded by the Institute for Scientific Research and Technology Development of the Flemish Government (IWT). We are grateful to two anonymous reviewers for their comments.

\section{References}

Abdelhalim, A. I. (1986) Thinking Paradise, Environmental Design: Journal of the Islamic Environmental Design Research Centre, 2, pp. 68-73.

Abdelhalim, A. I. (1988) A Ceremonial Approach to Community Building, in M. Bentley Sevcenko (Ed.) Theories and Principles of Design in the Architecture of Islamic Societies, pp. 139-148 (Cambridge, MA: Aga Khan Program for Islamic Architecture).

Abdelhalim, A. I. (1989) On Creativity, Imagination, and the Design Process, in I. Serageldin (Ed) Space for Freedom: The search for Architectural Excellence in Muslim Societies, pp. 236-237 (London: Butterworth Architecture).

Abdelhalim, A. I. (1996) Culture, Environment, and Sustainability: theoretical notes and reflection on a community park project in Cairo, in W. Reilly (Ed.) Sustainable Landscape Design in Arid Climates, pp. 49-61 (Geneva: Aga Khan Trust for Culture).

Abdelwahab, M. A. (2009) Reading Place: the Cultural Park for Children, Forum, 9, pp. 1-12.

Abdelwahab, M. A. (2010) Cairo, Khōra and deconstruction: Towards a reflexive reading of place, unpublished PhD thesis, School of Architecture, Planning and Landscape, Newcastle University, Newcastle-upon-Tyne.

Abdelwahab, M. (forthcoming) A Reflexive Reading of Urban Space (Farnham: Ashgate).

Aga-Khan-Award-for-Architecture, Online Database, Available at: http://www.akdn.org/akaa.asp (Accessed: 29 January 2009).

Akbar, J. (1992) Cultural Park for Children, Cairo Egypt, The Aga Khan Award for Architecture, AKTC. Available at http://www.akdn.org/aktc.asp (Accessed: 29 January 2009).

Albrechts, L. (2001) In Pursuit of New Approaches to Strategic Spatial Planning. A European Perspective, International Planning Studies, 6(3), pp. 293-310.

Albrechts L. (2003) Planning and power: towards an emancipatory planning approach, Environment and Planning C: Government and Policy, 21(6), pp. 905-924.

Albrechts L., Healey, P. \& Kunzmann, K. (2003) Strategic spatial planning and regional governance in Europe, Journal of the American Planning Association, 69(2), pp.113-129.

Albrechts, L. \& Mandelbaum, S. (2005) A New Context for Planning?, in: L. Albrechts \& S. Mandelbaum (Eds) The Network Society. A New Context for Planning, pp. 1-8 (London and New York: Routledge).

Alden, J., Albrechts, L. \& da Rosa Pires, A. (2001) In search of new approaches for planning, in: J. Alden, L. Albrechts \& A. da Rosa Pires (Eds) The changing institutional landscape of planning, pp. 1-7 (Aldershot: Ashgate).

Amin, A. (2004) Regions unbound: towards a new politics of place, Geografiska Annaler: Series B, Human Geography, 86(1), pp. $33-44$.

Amin, A. (2012) Land of Strangers (Cambridge: Polity Press).

Amin, A. \& Thrift, N. (2005) What's left? Just the future, Antipode, 37(2), pp. 220-238.

Appadurai, A. (1990) Disjuncture and Difference in the Global Cultural Economy, Theory Culture Society, 79(2), pp. 295-310.

Balducci, A. (2010) Strategic Planning as a Field of Practices, in: M. Cerreta, G. Concilio \& V. Monno (eds.) Making Strategies in Spatial Planning Knowledge and Values, Urban and Landscape Perspectives, pp. 47-65 (Amsterdam: Springer).

Beeson, I. (1969) Cairo: a millennial, Saudi Aramco World, 20(5), p. 24-30.

Bourdieu, P. (1984) [1979] Distinction: A Social Critique of the Judgement of Taste, trans. R. Nice (London: Routledge).

Campbell, H. (2006) Just planning: the art of situated ethical judgement, Journal of Planning Education \& Research, 26(1), pp. 92106.

Concilio, G. (2010) Bricolaging Knowledge and Practices in Spatial Strategy-Making, in: M. Cerreta, G. Concilio \& V. Monno (Eds) Making Strategies in Spatial Planning Knowledge and Values, Urban and Landscape Perspectives, pp. 281-301 (Amsterdam: Springer).

DeLanda, M. (2004) Intensive Science and Virtual Philosophy (London: Continuum).

Deleuze, G. \& Guattari, F. (1987) A Thousand Plateaus: Capitalism and Schizophrenia (Minneapolis: University of Minnesota Press).

Dewsbury, J. D. (2000) Performativity and the event: enacting a philosophy of difference, Environment \& Planning D, Society \& Space, 18(4), pp. 473-496.

Doel, M. (1996) A hundred thousand lines of flight: a machinic introduction to the nomad thought and scrumpled geography of Gilles Deleuze and Félix Guattari, Environment and Planning D, Society and Space, 14(4), pp. 421-439.

Elshaks, S. \& Shoshkes, E. (1998) Islamic cities in the world, in F. Lo \& Y. Yeung Y. (Eds) Globalization and the world of large cities, pp. 228-270 (New York: United Nations University Press).

Fainstein, S. (2001) Competitiveness, Cohesion, and Governance: Their Implications for Social Justice, International Journal of Urban and Regional Research, 25(4), pp. 884-8.

Flyvbjerg, B. (1998) Rationality \& Power (Chicago: University of Chicago Press).

Forester, J. (1989) Planning in the Face of Power (Berkeley, CA: California University Press).

Friedmann, J. (2004) Strategic Spatial Planning and the Longer Range, Planning Theory and Practice, 5(1), pp. 49-56.

Giddens, A. (1984) The constitution of society (Cambridge: Polity Press).

Grosz, E. (2001) Architecture from the Outside (Cambridge, MA: MIT Press).

Gualini, E. (2001) Planning and the intelligence of institutions. Interactive approaches to territorial policy-making between institutional design and institution-building (Aldershot: Ashgate).

Habermas, J. (1984) [1981] The Theory of Communicative Action: Vol. 1: Reason and the Rationalization of Society, trans. T. McCarthy (Boston, MA: Beacon Press). 
Habermas, J. (1987) [1981] The Theory of Communicative Action: Vol. 2: Lifeworld and System: A Critique of Functionalist Reason, trans. T. McCarthy ( Boston, MA: Beacon Press).

Harvey, D. (2005) A Brief History of Neoliberalism (New York: Oxford University Press).

Hassan, F. (1996) The Cultural Garden in Sayyida Zeinab: an expensive toy - interview with Dr Abdelhalim Ibrahim Abdelhalim' Middle East Report, 202: 13, http://www.merip.org/mer.mer202 (Accessed: 29 January 2009).

Healey, P. (1999) Institutionalist analysis, communicative planning and shaping places, Journal of Planning Education and Research, 19(2), pp. 111-121.

Healey, P. (2004) The treatment of space and place in the new strategic spatial planning in Europe, International Journal of Urban and Regional Research, 28(1), pp. 45-67.

Healey, P. (2005) On the project of institutional transformation in the planning field. Commentary on the contributions, Planning Theory, 4(3), pp. 301-310.

Healey, P. (2006) Relational Complexity and the Imaginative Power of Strategic Spatial Planning, European Planning Studies, 14 (4), pp. 525-546.

Healey, P. (2007) Urban Complexity and Spatial Strategies: towards a relational planning for our times (London and New York: Routledge).

Healey, P. (2008) Making choices that matter: the practical art of situated strategic judgment in spatial strategy-making, in J. Van den Broeck J., F. Moulaert \& S. Oosterlynck (Eds) Empowering the Planning Fields: ethics, creativity and action, pp. 23-41 (Leuven: Acco).

Healey, P. (2010) Introduction to Part One: Conceptual challenges from perspectives on spatial planning practice, in J. Hillier \& P. Healey (Eds) The Ashgate Research Companion to Planning Theory: Conceptual Challenges for Spatial Planning, pp. 37-56 (Farnham: Ashgate).

Hendler, S (1995) Planning Ethics (New Brunswick, NJ: Centre for Urban Policy Research).

Hillier, J. (2002) Shadows of Power (London: Routledge).

Hillier, J. (2003) Agonising Over Consensus - Why Habermasian Ideals Cannot be 'Real', Planning Theory, 2(1), pp. 37-59.

Hillier, J. (2007) Stretching beyond the Horizon: A Multiplanar Theory of Spatial Planning and Governance (Aldershot: Ashgate).

Hillier, J. (2010) Post-structural Complexity: Strategic Navigation in an Ocean of Theory and Practice, in: M. Cerreta, G. Concilio \& V. Monno (eds.) Making Strategies in Spatial Planning Knowledge and Values, Urban and Landscape Perspectives, pp. 87-97 (Amsterdam: Springer).

Hillier, J. (2011) Strategic Navigation across Multiple Planes: towards a Deleuzean-inspired methodology for strategic spatial planning, Town Planning Review, 82(5), pp. 503-527.

Howe, E. (1994) Acting on Ethics in City Planning Ethics (New Brunswick, NJ: Centre for Urban Policy Research).

Innes, J. \& Booher, D. (1999) Consensus-building as role-playing and bricolage, Journal of the American Planning Association, $65(1)$, pp. 9-26.

Jessop B. (2001) Institutional (re)turns and the strategic-relational approach, Environment and Planning A, 33(7), pp. $1213-1235$.

Jessop, B., Brenner, N. \& Jones, M. (2008) Theorizing sociospatial relations, Environment and Planning D: Society and Space, 26(3), pp. 389-401.

Jones, M. (2009) Phase space: Geography, relational thinking, and beyond, Progress in Human Geography, 33(4), pp. 487-506.

Lehtovuori, P. (2010) Experience and Conflict: The Production of Urban Space. (Farnham: Ashgate).

MacCann, E. \& Ward, K. (2010) Relationality/territoriality: Toward a conceptualization of cities in the world', Geoforum, 41(2), pp. $175-184$.

Massey, D. (2005) For Space (London: Sage).

Moulaert, F. (2009) Social innovation. Institutionally embedded, territorially (re)produced, in: D. MacCallum, F. Moulaert, J. Hillier \& S. Vicari Haddock (Eds) Social innovation and territorial development (Aldershot: Ashgate).

Moulaert, F. \& Mehmood, A. (2009) Spatial planning and institutional design: what can they expect from transition cost economics, in M. Geyer (Ed) Urban Policy Handbook vol. II , pp. 199-211 (Cheltenham: Edward Elgar).

Pløger, J. (2004) Strife - urban planning and agonism, Planning Theory, 3(1), pp. 71-92.

Sandercock, L. (1998) Towards Cosmopolis: planning for multicultural cities (London: John Wiley).

Sassen, S. (1991) The Global City (Princeton: Princeton University Press).

Servillo, L. \& Van den Broeck, P. (2012) The social construction of planning systems. A strategic-relational institutionalist approach, Planning Practice and Research, 27(1), pp. 41 - 61

Van den Broeck, P. (2010) De sociale constructie van plannings- en projectinstrumenten. Onderzoek naar de socio-technische dynamiek in het 'Eerste Kwartier' in Antwerpen, [The social construction of instruments for planning and development. Analysis of the socio-technical dynamics in the 'First Quarter' in Antwerp], PhD thesis (Leuven: KU Leuven).

Van den Broeck P. (2011) Analysing social innovation through planning instruments: a strategic-relational approach, in S. Oosterlynck, J. Van den Broeck, L. Albrechts, F. Moulaert \& A. Verhetsel (Eds) Strategic Spatial Projects. Catalysts for Change, pp. 52-78 (London and New York: Routledge).

Versteeg, W. \& Hajer, M. (2010). Is this how it is, or is this how it is here? Making sense of politics in planning, in J. Hillier \& P. Healey (Eds) The Ashgate Research Companion to Planning Theory: Conceptual Challenges for Spatial Planning, pp. 159-182 (Farnham: Ashgate).

Vigar, G., Graham, S. \& Healey, P. (2005) In Search of the City in Spatial Strategies: Past Legacies, Future Imaginings, Urban Studies, 42(8), pp. 1391-1410. 